\title{
Being a Woman in China Today: A demography of gender
}

\section{Isabelle Attané}

Translator. Elizabeth Guill

\section{OpenEdition \\ Journals}

\section{Electronic version}

URL: http://journals.openedition.org/chinaperspectives/6013

DOI: 10.4000/chinaperspectives.6013

ISSN: 1996-4617

\section{Publisher}

Centre d'étude français sur la Chine contemporaine

\section{Printed version}

Date of publication: 7 December 2012

Number of pages: 5-15

ISSN: 2070-3449

\section{Electronic reference}

Isabelle Attané, « Being a Woman in China Today: A demography of gender », China Perspectives

[Online], 2012/4 | 2012, Online since 01 December 2012, connection on 28 October 2019. URL : http:// journals.openedition.org/chinaperspectives/6013; DOI : 10.4000/chinaperspectives.6013 


\title{
Being a Woman in China Today:
}

A Demography of Gender

\author{
ISABELLE ATTANÉ
}

\begin{abstract}
The aim of this article is on the one hand, to draw up a socio-demographic inventory of the situation of Chinese women in the prevailing early twenty-first century context of demographic, economic, and social transition, and on the other hand, to draw attention to the paradoxical effects of these transitions whilst taking into account the diversity of the realities women are experiencing. In conclusion, it raises the possibility of changes in gender relationships in China, where there are, and will continue to be, fewer women than men, particularly in adulthood.
\end{abstract}

KEYWORDS: China, demography, gender, status of women, education, employment, demographic masculinity, discrimination against women.

I do not think that men and women are on an equal footing. I live in a world dominated by men, and I sense this impalpable pressure every day. It's not that men don't respect us. My husband cooks for me and does a lot around the house, but I still feel male chauvinism in the air. In truth, men do not really consider us to be their intellectual equals.

\section{Cao Chenhong, senior manager in a Beijing company.}

A fter three decades of Communism followed by three decades of economic liberalism, Chinese society remains, in many ways, very attached to its social and family traditions. (1) In recent years, however, it has shown a remarkable faculty for adaptation to the process of globalisation in which it is now a stakeholder. Since they can prove difficult to interpret, the transformations that have affected China since the 1980s are sometimes perplexing. It is not always easy to distinguish between changes that are part of the continuity of longstanding social practices, and others, sometimes sudden, that ultimately prove to be ad hoc expressions in reaction to the new constraints and opportunities imposed by socio-economic changes and a globalised society. The analysis of social, just as much as economic and political, transformations is moreover sometimes so delicate that it quite rightly leads us to conclude that a paradox exists. (2)

The attitude of Chinese society towards women, which also displays its quota of paradoxes, testifies to this duality - itself all the more complex since it remains marked by the search for equality between the sexes that prevailed during the Communist parenthesis. Nonetheless, understanding and measuring transformations in the status of women since the economic reforms remains essential if we are to arrive at a more global understanding of contemporary Chinese society, its representations, and the changes it is experiencing. In fact, the place given to women, measured by various indicators relating to education, employment, demography, and health, is a generally reliable indicator of the radical changes affecting society. Yet this is a paradox in itself: although in certain respects, notably regarding education and health, improvements in the situation of Chinese women in the absolute are indisputable, in others, their relationships with men remain all the more unequal for being part of a demographic context that is un- favourable to them, thereby testifying to an unquestionable deterioration in certain aspects of their situation.

The aim of this article is to draw up a socio-demographic inventory of the situation of Chinese women in the prevailing early twenty-first century context of demographic, economic, and social transition on the one hand, and on the other hand, to draw attention to the paradoxical effects of these transitions, whilst taking into account the diversity of the realities the women are experiencing. In conclusion, the article will raise the possibility of changes in gender relationships in China, where there are, and will continue to be, fewer women than men, particularly in adulthood. The article is based mainly on the partial results of three surveys on the social status of women (Zhongguo funü shehui diwei chouyang diaocha) carried out jointly by the Federation of Chinese women and the National Office of Statistics in 1990, 2000, and 2010. These surveys (referred to here as ACWF1990, ACWF-2000, and ACWF-2010), (3) organised with the specific aim of measuring inequality between the sexes and gender differences, paint a wide-ranging picture of the social realities experienced by Chinese women over the last two decades. ${ }^{(4)}$ These quantitative surveys, the only ones to

1. Martin King Whyte, "Continuity and Change in Urban Chinese Family Life," The China Journal, No. 53, January 2005, pp. 9-33; Merril Silverstein, Zhen Cong, and Li Shuzhuo, "Intergenerational Transfers and Living Arrangements of Older People in Rural China: Consequences for Psychological Well-Being," Journal of Gerontology, Vol. 61. No. 5, 2006, pp. 256-266.

2. Guy Olivier Faure and Tony Fang, "Changing Chinese Values: Keeping up with paradoxes," International Business Review, Vol. 17, No. 2, 2008, pp. 194-207; Jean-Louis Rocca, Une sociologie de la Chine (A sociology of China), Paris, La Découverte, 2010; Martin King Whyte, "Filial Obligations in Chinese Families: Paradoxes of Modernization," in Charlotte Ikels (ed.), Filial Piety: Practice and Discourse in Contemporary East Asia, Stanford (CA), Stanford University Press, 2004.

3. ACWF-2000, "Di er qi Zhongguo funü shehui diwei chouyang diaocha zhuyao shuju baogao" (Executive Report of the second sample survey on Chinese Women's Social Status), 2001, www.stats.gov.cn/tjgb/qttjgb/qgqttjgb/t20020331_15816.htm (consulted on 25 September 2012); ACWF-2010, "Di san qi Zhongguo funü shehui diwei diaocha zhuyao shuju baogao" (Executive Report of the third sample survey on Chinese Women's Social Status), Funü yanjiu lun cong, Vol. 6, No. 108, 2011, pp. 5-15. The data from ACWF-1990 referred to here is taken from ACWF2000.

4. These surveys in the form of questionnaires were each given to representative samples of tens of thousands of women and men aged between 18 and 64 years from different provinces and milieux (urban, rural, population with experience of migration, Han/ethnic minorities, etc.).The quantitative data obtained from these was supplemented by information taken from in-depth interviews and discussion groups. For more details on the samples and methodology of these surveys, see ACWF-2000 and ACWF-2010. With no access to raw data, the results presented here were taken from the Executive reports (see above). 
exist on the subject, nonetheless present limitations related to the closed questionnaire collection method. Although they do not provide all the explanations, they nonetheless enable us to understand the processes at work on the question of women and gender relationships. The data from these surveys will occasionally be supplemented by that taken from other sources, notably the 1990, 2000, and 2010 censuses.

\section{The situation of women in China today: Taking stock}

China is one of the world's developing countries in which demands for the emancipation of women and the struggle for equality between the sexes are both among the most longstanding of political concerns - the first movements in favour of women date back to the mid-nineteenth century ${ }^{(5)}$ - and the most in evidence today. As early as the 1950s, concrete action was organised in favour of the development of women's work outside the home and for the equality of spouses within the family. ${ }^{(6)}$ China was also one of the first countries to ratify, in 1980, the United Nations International Convention on the elimination of all forms of discrimination against women (CEDAW).

The relatively early mobilisation of the state and civil society partly explains why China now possesses a solid body of legislation for the defence of the rights and interests of women. Thanks to the 1954 Constitution, followed by that of 1982, the law gives men and women equal rights: "Women have the same rights as men in all spheres of political, economic, cultural, and social life, including family life." "(7) This equality of rights and the fight against discrimination have, moreover, been regularly confirmed, mainly in successive laws on marriage, by the "Law on the Protection of Rights and Interests of Women" (1992) and the "Law on Maternal and Infant Health Care" (1994). ${ }^{(8)}$

International initiatives in favour of the autonomy of women and equality between the sexes are not unrelated to this major mobilisation on the part of China, however. In particular, the Chinese government quickly understood that the legitimacy of the country in the front ranks of world powers was dependent on its adherence to important international principles, notably those relating to the rights of women, and that it was important to support the pursuit of gender equality in order to ensure harmonious, sustainable development within the globalisation process. Besides this, in the 1990s, the government recognised that some women had remained on the sidelines of the modernisation process and that subsequent to the economic reforms their situations had become very uneven, depending on where they lived and their social class, especially with regard to their needs in terms of subsistence and the development and preservation of their rights and interests. The Chinese government therefore rapidly echoed the United Nations International Conference on Population and Development (Cairo, 1994) and the 4th World Conference on Women (Beijing, 1995), which marked a decisive step in the promotion of the status of women in the world, ${ }^{(9)}$ as did the Millennium Development Goals (MDGs). ${ }^{(10)}$ The rights and interests of women and their equality with men were from then on permanently on the political agenda, notably through three successive programs for the development of women (Zhongguo funü fazhan gangyao) launched from 1995 onward. (11) Lastly, the political objective of reducing social and economic inequalities, which since the 2000s has been an important element in the development of a "harmonious society" (hexie shehui), may also benefit women, in particular by ensuring a more rigorous application of the laws that protect them and by facilitating access to health, education, social security cover, and employment, etc. ${ }^{(12)}$

The Chinese government's stance on the rights of women and equality between the sexes has not, however, put an end to traditional stereotypes of the roles and duties of men and women within the family and society - far from it - or to the often very unequal situations these stereotypes generate, in particular since the economic reforms. ${ }^{(13)}$ In 1994, a State Council (1994) document stipulated: "China subscribes to the principle of equality between the sexes set down in the United Nations Charter and promises to respect it. The government is convinced that equality between the sexes will become a reality to the extent that women will be able to participate in development as equal partners of men." (14) $A$ decade later, however, the Chinese government recognised that "deep-seated inequalities continue to exist between regions regarding the status of women, traditional sexual stereotypes persist, the rights of women are ignored in many places, [and that] a great deal of work remains to be done to improve the situation of Chinese women if their equality with men is to become a reality." ${ }^{(15)}$ As recently as 2011, the further deterioration of the sex ratio at birth revealed by the sixth census (2010), the consequence of massive discrimination against girls, led President $\mathrm{Hu}$ Jintao to confirm that significant inequalities between the sexes persist. ${ }^{(16)}$

\section{Education, employment, salaries: Chinese women still lag behind}

Different treatment for men and women can easily be seen in many areas of society. In China, inequalities between the sexes remain not only as regards access to education, employment, and health, but also in matters of

5. Danièle Elisseeff, La femme au temps des Empereurs de Chine (Women in the time of the Chinese Emperors), Paris, Stock, 1988.

6. See Tania Angeloff and Marylène Lieber, "Equality, Did You Say? Chinese feminism after 30 years of reforms," in this issue; Kay Ann Johnson, Women, the Family and Peasant Revolution in China, Chicago, University of Chicago Press, 1983.

7. Extract from Article 48 of the Constitution of the People's Republic of China, 1982

8. All-China Women's Federation, 2012, www.women.org.cn/english/english/laws/mulu.htm (consulted on 25 September 2012). For further details on the various laws and regulations intended to protect the rights and interests of women in China, see in particular Isabelle Attané, Une Chine sans femmes? (A China without women?), Paris, Perrin, 2005, pp. 171-174.

9. Chapter 4 of the Action Program adopted during the Cairo International Population Conference in 1994 begins thus: "The emancipation and empowerment of women and improvements in their political, social, economic and health status is an end in itself"; "The fundamental rights of women and girls are inalienable and indivisible from the universal rights of Man" (Extract from the Action Program of the 4th World Conference on Women held in Beijing, 4-15 September 1995).

10. The member-states of the United Nations agreed on eight essential goals to be reached by 2015 . These "Millennium Development Coals" (MDGs) are as follows: to eradicate extreme poverty and hunger; to achieve universal primary education; to promote gender equality and empower women; to reduce infant mortality; to improve maternal health; to combat HIV/AIDS, malaria, and other diseases; to ensure environmental sustainability; to develop a global partnership for development.

11. Program for the Development of Chinese Women 2001-2010, www.china.org.cn/english/features/cw/140979.htm (consulted on 25 September 2012). See also Tania Angeloff and Marylène Lieber, "Equality, Did You Say? Chinese feminism after 30 years of reforms," in this issue.

12. Jamie Burnett, "Women's Employment Rights in China: Creating Harmony for Women in the Workplace," Indiana Journal of Global Legal Studies, Vol. 17, No. 2, 2010, pp. 289-318, www.repository.law.indiana.edu/ijgls/vol17/iss2/8 (consulted on 25 September 2012).

13. Wang Zheng, "Gender, employment, and women's resistance," in Elizabeth J. Perry and Mark Selden (eds.), Chinese society: Change, conflict and resistance, London, Routledge, 2010, pp. 162186.

14. Isabelle Attané, Une Chine sans femmes ?(A China without women?),op. cit.

15. Gender Equality and Women's Development in China, available on China.org.cn, "China Publishes Gender Equality White Paper," www.china.org.cn/english/2005/Aug/139404.htm (consulted on 25 September 2012)

16. "Census data demonstrates positive changes in China over the past decade," http://english.peopledaily.com.cn/90001/90776/90882/7366454.html (consulted on 25 September 2012). 
Table 1 - Level of Education for women, 1990-2010.

\begin{tabular}{|c|c|c|c|c|c|c|}
\hline & \multicolumn{2}{|c|}{1990} & \multicolumn{2}{|c|}{2000} & \multicolumn{2}{|c|}{2010} \\
\hline & Urban & Rural & Urban & Rural & Urban & Rural \\
\hline \multicolumn{7}{|c|}{ Breakdown of educational level } \\
\hline $\begin{array}{l}\text { Percentage of } \\
\text { women with no } \\
\text { education }\end{array}$ & 10.9 & 34.7 & \multirow[b]{2}{*}{20.8} & \multirow[b]{2}{*}{58.8} & 3.5 & 6.6 \\
\hline $\begin{array}{l}\text { Percentage of } \\
\text { women with } \\
\text { primary level } \\
\text { education }\end{array}$ & 19.8 & 36.1 & & & 10.3 & 29.4 \\
\hline $\begin{array}{l}\text { Percentage of } \\
\text { women with at } \\
\text { least a secondary } \\
\text { education }\end{array}$ & 36.1 & 6.7 & 44.4 & 8.4 & 54.2 & 18.2 \\
\hline \multicolumn{7}{|c|}{ Average length of education (in years) } \\
\hline Women & \multicolumn{2}{|c|}{4.7} & \multicolumn{2}{|c|}{6.1} & \multicolumn{2}{|c|}{8.8} \\
\hline Men & \multicolumn{2}{|c|}{6.6} & \multicolumn{2}{|c|}{7.6} & \multicolumn{2}{|c|}{9.1} \\
\hline
\end{tabular}

Sources : ACWF-2010. op. cit.

inheritance, salaries, political representation, and decision-making within the family. ${ }^{(17)}$

Education counts amongst the factors that improve the status of women in that it tends to reduce the birth rate and encourages them to take better care of their health. ${ }^{(18)}$ Above all, by facilitating access to worthwhile, decently-paid professions, it favours their economic emancipation and in the process, since it changes the power relationship with men, their emancipation within the family. From this point of view, great progress has been made in recent years. Firstly, the spread of primary education amongst the younger generations has significantly reduced the percentage of women (18-64 years old) with no education. In 2010, this fell to 6.6 percent in rural areas and to 3.5 percent in urban areas (Table 1). Improvements can also be seen in access to secondary and higher education, in particular the tripling, between 1990 and 2010, of the share of women receiving this type of education in rural areas and a doubling of the proportion in urban areas. Although secondary and higher education remain, on the whole, the preserve of a minority of Chinese women (scarcely more than a third of them had access to one and/or the other), recent changes have been indisputably positive: in 20 years, the average length of women's education almost doubled, from 4.7 years in 1990 to 8.8 in 2010, thereby gradually narrowing the gap with men (6.6 years in 1990 and 9.1 years in 2010).

Although in China's eastern cities young people of both sexes now have access to educational resources in a relatively egalitarian manner, considerable geographical disparities remain, particularly in rural areas. In 2010, for example, in the centre and west of the country, rural women had only attended school for an average of 6.8 years, 2.2 years less than those living in the rural zones of the municipalities of Beijing and Tianjin. ${ }^{(19)}$ It is true that in rural areas, the added value of education, in particular for girls, is not always understood, all the more so since the inherent costs have become prohibitive for many families since the reform of the education system in the 1980s. As a general rule, family expectations for girls remain lower than for boys, although the gap between the sexes from this point of view is becoming narrower. ${ }^{(20)}$ The ACWF-2000 survey shows in fact that leaving school early is more frequently due to the parents' decision in the case of girls (36.8 percent) than in the case of boys (27.9 percent). Although financial difficulties remain an important reason for leaving school early for boys as well as girls (for 69.8 percent and 68.1 percent respectively), more parents consider education to be unnecessary for girls (for 9.1 percent of them, and for 3.5 percent of boys).

Employment for Chinese women has also undergone major transformations over the last 20 years, but in a way that is considerably less favourable to them. Although sparse, data from surveys on the status of women - partially supplemented by data from censuses - show that the employment rate for women is still amongst the highest in the world. In the country as a whole, almost three women out of four work, a very high level if we consider the situation in other big countries in the region. In India, for example, only a little over one woman out of three is officially employed, and in Japan, the Republic of Korea, and the Philippines, the figure is fewer than one out of two. (21)

The relative advantage of Chinese women would not seem to be permanently established, however. Indeed, as with men though to a lesser extent, employment rates for women have fallen significantly since the 1990s,

17. Laurel Bossen, "Missing Girls, Land and Population Controls in Rural China," in Isabelle Attané and Christophe Guilmoto (ed.), Watering the neighbour's garden: The growing demographic female deficit in Asia, Paris, Cicred, 2007, pp. 207-228; Jamie Burnett, "Women's Employment Rights in China," art. cit:; Lin Tan, Zhongguo xingbie pingdeng yu funü fazhan pinggu baogao, 1995-2005 (Report on gender equality and women's development in China 1995-2005), Beijing, Social Sciences Academic Press, 2006

18. John Bongaarts, "Completing the fertility transition in the developing world:The role of educational differences and fertility preferences," Policy research division working papers, No. 177, New York, Population Council, 2003, www.popcouncil.org/pdfs/wp/177.pdf (consulted on 25 September 2012).

19. ACWF-2010, op. cit

20. Jennifer Adams and Emily C. Hannum, "Girls in Gansu, China: Expectations and aspirations for secondary schooling," 2008, http://repository.upenn.edu/gansu_papers/4 (consulted on 25 September 2012).

21. Data from 2009. See Charting International Labor Comparison, 2011 Edition, Bureau of Labor Statistics, United States Department of Labor, www.bls.gov/fls/chartbook/section2.pdf (consulted on 25 September 2012). 
Table 2 - Employment and income for women and men, 1990-2010.

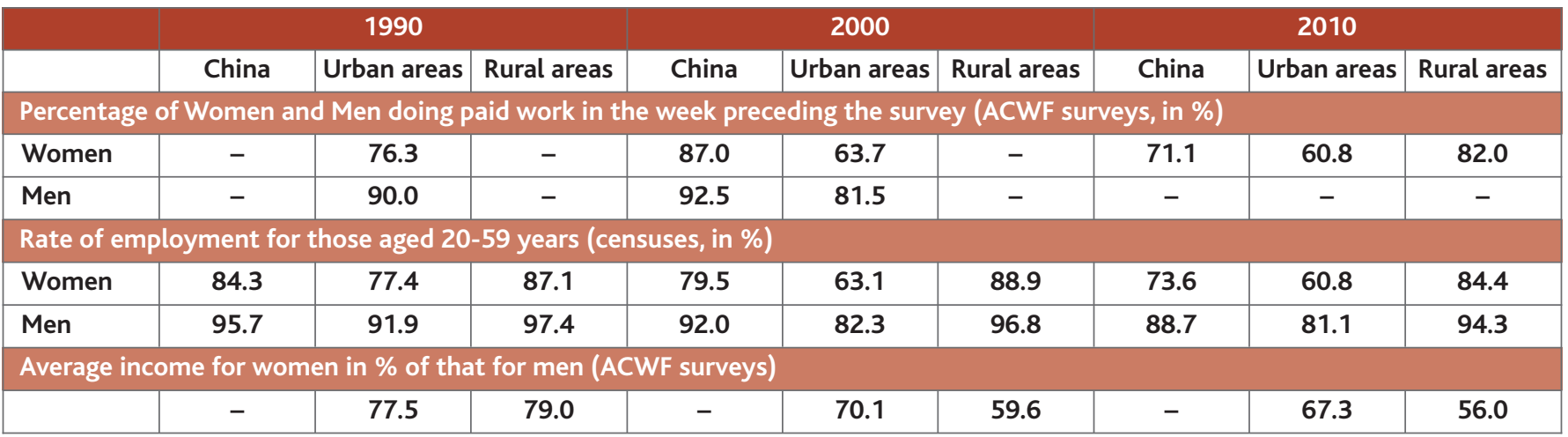

Sources : ACWF-2000. op. cit.; ACWF-2010. op. cit.; Population Census Office and National Bureau of Statistics of China, Zhongguo 1990 nian renkou pucha ziliao (Tabulation on the 1990 Population Census of the People's Republic of China), Beijing, Zhongguo renkou chubanshe, 1993 ; Population Census Office and National Bureau of Statistics of China, Zhongguo 2000 nian renkou pucha ziliao (Tabulation on the 2000 Population Census of the People's Republic of China), Beijing, China Statistics Press, 2002. 1906 p. ; Population Census Office and National Bureau of Statistics of China, Zhongguo 2010 nian renkou pucha ziliao (Tabulation on the 2010 Population Census of the People's Republic of China), Beijing, China Statistics Press, 2012.

mainly in the cities. Particularly affected by the redundancies following the dismantling of labour units in the 1990s, ${ }^{(22)}$ and finding it more difficult than men to find a new job, (23) urban women are now returning to the home in force: in 1990, 76.3 percent of them were in paid work compared to only 60.8 percent in 2010 (Table 2). The situation is even more flagrant in certain regions. In 2005, the percentage of women in employment had fallen to 45 percent in Jilin, whereas for women in the cities of Heilongjiang, the figure was 35 percent. ${ }^{(24)}$ Although rural women are not totally spared by this trend, their effective participation in economic activities (mainly agricultural) remains far greater (82 percent in 2010) than in urban areas. The gap between urban areas and the countryside is therefore widening, underlining the effect that the reorganisation and privatisation of the Chinese economy, particularly in the industrial sector, is having on employment for women in the cities.

On the whole, even though equality with men was never attained even during the collectivist period, (25) Chinese women have, since the 1950s, gained more economic independence and are to a greater extent mistresses of their own personal and professional choices. (26) Particularly since the reforms, new opportunities have been offered them, mainly as a result of the boom in higher education for some, which has allowed them to obtain jobs requiring more qualifications and which are better paid than in the past. ${ }^{(27)}$ A feminine elite is even emerging, embodied above all by the microcosm of women entrepreneurs whose social success has become one of the symbols of the Chinese economic boom. (28) This phenomenon apart, the economic reforms have on the whole been harmful to women, in two ways in particular. On the one hand, because they are now exposed to economic insecurity (linked mainly to unemployment, the difficulty of finding a new job, and more frequent compulsory early retirement) to a greater extent than men, and on the other, because the sexual discrimination in the labour market from which they had been relatively sheltered by the employment system within the work units has removed them still further from the sexual equality promised them, in particular by the Constitution. ${ }^{(29)}$ The employment market, which has become highly competitive, now reserves the lion's share for men. Many job offers are reserved for men, ${ }^{(30)}$ and women continue to hit the "glass ceiling." (31) In addition, unemployment officially remains 50 percent higher for women than for men: 12 percent and 8 percent respectively in 2004, ${ }^{(32)}$ and in 2010, there were also twice as many women
(10 percent as against 4.5 percent of men) who declared being or having been victims of discrimination in the workplace. For 70 percent of the women in this situation, the causes were stated to be unfair dismissal, mainly following marriage or pregnancy, the absence of promotion related to gender, a lower salary than that of men for doing the same work, and the disdain regularly displayed towards them in the workplace. ${ }^{(33)}$ Insecurity for women in the labour market quite logically renders them more vulnerable in economic terms, since whilst a large majority of men aged 45-59 years old (87.1 percent) still live on the income they earn from work, this is only the case for 65.0 percent of women in the same age group. One in five (19.6 percent) is financially dependent on a member of her family as against 4.7 percent of men. ${ }^{(34)}$

22. Wang Zheng, "Gender, employment, and women's resistance," art. cit;; Liu Jieyu, Gender and Work in Urban China, Women Workers of the Unlucky generation, London, Routledge, 2007.

23. Zhi Huayong, Huang Jikun, Huang Zhurong, Scott Rozelle, and Andrew Mason, "Impact of the Global Financial Crisis in Rural China: Gender, Off-farm Employment, and Wages," Center for Chinese Agricultural Policy, 2012, http://en.ccap.org.cn/show.php?contentid=3719 (consulted on 25 September 2012).

24. All China Women's Federation, Annual Report on Gender equality and women's development in China, Beijing, Social Sciences Academic Press, 2008, pp. 409-410.

25. Kay Ann Johnson, Women, the Family and Peasant Revolution in China, op. cit.

26. Lin Tan, "Quel statut pour la femme chinoise ?" (What status for the Chinese woman?), in Isabelle Attané (ed.), La Chine au seuil du Xxe siècle: Questions de population, questions de société (China at the dawn of the twenty-first century: Questions of population, questions of society), Paris, INED, 2002, pp. 329-348; Yunxiang Yan, "Cirl Power:Young Women and the Waning of Patriarchy in Rural North China," Ethnology, Vol. 45, No. 2, 2006, pp. 105-123.

27. Tania Angeloff, "La Chine au travail (1980-2009) : emploi, genre and migrations" (China at work [1980-2009]: Employment, gender and migrations), Travail, genre and sociétés (Work, gender and societies), Vol. 1, No. 23, 2010, pp. 79-102.

28. Song Jingli, "China's female entrepreneurs dare to try," China Daily, 15 December 2011; Deng Shengliang, Xu Wang and Ilan Alon, "Framework for female entrepreneurship in China," International Journal of Business and Emerging Markets, Vol. 3, No. 1, 2011, pp. 3-20.

29. Jamie Burnett, "Women's Employment Rights in China," art. cit:; Gale Summerfield, "Economic reform and the employment of Chinese women," Journal of Economic Issues, Vol. XXVIII, No. 3, 1994.

30. CERN, 2011. China Education and Research network, "Nü daxuesheng jiuye kunjing diaocha: Liu cheng ceng zaoyu xingbie xianzhi" (Survey on the employment of female college students: 60 percent have experienced gender-related limitations), http://edu.sina.com.cn/j/2011-0727/1357205033.shtml (consulted on 25 September 2012).

31. Tania Angeloff, "La Chine au travail ...," art. cit.

32. Annual Report on Gender equality and women's development in China, op. cit., p. 86

33. ACWF-2010, op. cit

34. Population Census Office and National Bureau of Statistics of China, Zhongguo 2010 nian renkou pucha ziliao (Tabulation on the 2010 population census of the People's Republic of China), Beijing, China Statistics Press, 2012 
Although the Communist parenthesis favoured the employment of women outside the home, it did not put an end to the social prejudices that place a lower value, professionally, on women's skills than on those of men. ${ }^{(35)}$ In 2000, a third of those interviewed (33.3 percent of women and 34.0 percent of men) did not refute traditional ideas according to which "man is strong, woman is weak" (Nan qiang nü ruo) or "men's abilities are naturally superior to those of women" (Nanxing nengli tiansheng bi nüxing qiang). ${ }^{(36)}$ An independent survey (2009) confirmed the prevalence of this way of thinking, revealing that a third of those interviewed (37 percent of men and 33 percent of women) believe that if women have fewer career prospects it is because they have limited personal skills, a further third (32 percent of men and 28 percent of women) attribute it to insufficient physical stamina, and a quarter ${ }^{(37)}$ ( 22 percent of men and 28 percent of women) think it is because women are less devoted to their work and their career plan is not sufficiently ambitious. The survey also indicated that the majority of women interviewed (77.6 percent) feel that employment opportunities for men and women are unequal, a view shared by the men, but to a lesser degree (66.4 percent). ${ }^{(38)}$ In addition, even though inequalities in salary still exist, to the question "If a man and a woman do the same job (39) but the man is paid more, what is your opinion of the situation?", 20.5 percent of men replied that this was "very common or only natural" (as against 7.9 percent of women), 41.8 percent thought it "unfair but acceptable" (as against 40.6 percent of women), and only 20.0 percent considered it "unfair and unacceptable" (42.9 percent of women). ${ }^{(40)}$

Chinese society continues to attribute different and well-defined roles and spheres of influence to men and women. However, as Harriet Evans ${ }^{(41)}$ has shown, this dichotomy is hardly ever challenged. In fact, the majority of those questioned (61.6 percent and 54.8 percent respectively in 2010) continue to think that "men are turned towards society, women devote themselves to their family" (Nanren yinggai yi shehui wei zhu, nüren yinggai yi jiating wei zhu) (Graph 1). Most surprising, however, is that adhesion to this concept has risen over the last decade amongst both women and men (by 4 and 8 points respectively). Consistent with the previous statement but equally unexpected is the growing adhesion to the idea that for women "a good marriage is better than a career" (Gan de hao buru jia de hao). This conviction, now shared by almost half of women (48.0 percent in 2010 that is to say 10 points more than in 2000 - and 40.7 percent of men) reveals the deep-seated internalisation of masculine domination, by women even more than by men. Moreover, it reinforces the fact that unlike in Western societies, where women's work outside the home is increasingly judged, on a par with men's, to be more valuable than domestic tasks, this trend cannot be seen in China. ${ }^{(42)}$ Despite the obvious repercussions on the possibilities for the empowerment of women both in economic and symbolic terms, traditional gendered roles are therefore being reinforced today also as a result of the growing insecurity of the labour market for women - the better qualified included - a situation exacerbated by the economic crisis of the late 2000s. ${ }^{(43)}$ Women's insecurity in the labour market, mainly in the cities, is the result not only of the growing difficulty they are having in finding employment, but also of the increasing inequality between men's and women's salaries. In 1990, the average income of female city-dwellers had reached 77.5 percent that of males, but 20 years later, this percentage corresponded to only two-thirds of the average male income (67.3 percent). The relative deterioration in women's incomes has been still greater in the countryside, where these percentages fell from 79 percent in 1990 to 56 percent in 2010. The ACWF-2000 Survey shows that in the cities, almost

\section{Graph 1 - Acceptance of gendered roles by men and women (as a percentage).}

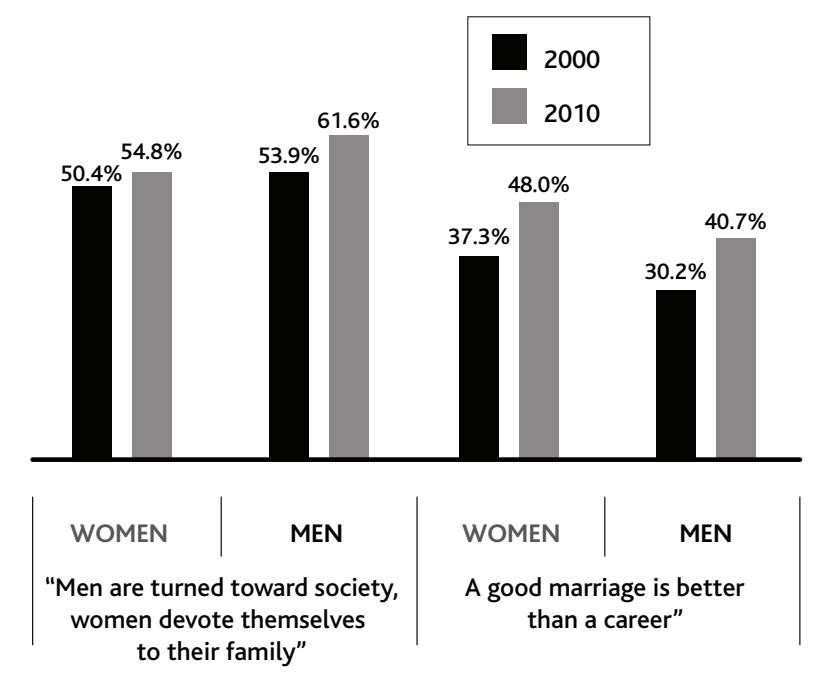

Sources : ACWF 2000. op. cit. ; ACWF-2010. op. cit.

one woman out of two (47.4 percent) received less than 5,000 yuan per year on average (against a little more than one man out of four: 28.4 percent), whilst 6.1 percent earned more than 15,000 yuan a year on average (as against 12.7 percent of men). Moreover, these differences in income have been accompanied by a slightly longer working day for women, who on average worked 9.6 hours a day in 2010, compared to 9.0 hours for men. ${ }^{(44)}$

These inequalities between the sexes with regard to levels of income and working hours is mainly due to the type of employment, with most women working in unskilled, badly paid jobs in agriculture, manufacturing, transport, shops, or services ${ }^{(45)}$ (Table 3). The feminisation of the agricultural workforce in particular partly explains these increasing differences in income: in 2000, 82.1 percent of rural women were employed full-time in agricultural activities (compared to 64.7 percent of men). ${ }^{(46)}$

\section{Women in private life: Roles still firmly gendered}

Private life is a place where, doubtless to an even greater extent than in public life, the evolution of the status of Chinese women is ambivalent. In many ways, particularly as regards their reproductive health (see Box 1),

35. Wei Guoying, "Gender Comparison of Employment and Career Development in China," Asian Women, Vol. 27, No. 1, 2011, pp. 95-113.

36. ACWF-2000, op. cit.

37. All the causes have not been given here. In total, all the causes combined exceed 100 percent because several answers to this question were allowed.

38. Wei Guoying, "Gender Comparison of Employment and Career Development in China," art. cit.

39. Tania Angeloff, "La Chine au travail...," art. cit.

40. Wei Guoying, "Gender Comparison of Employment and Career Development in China," art. cit.

41. Harriet Evans, The Subject of Gender: Daughters and Mothers in Urban China, Lanham/Boulder/New York/Toronto/Plymouth, Rowman \& Littlefield Publishers, 2008.

42. Zuo Jiping and Bian Yanjie, "Gendered resources, division of housework, and perceived fairness Case in urban China," Journal of Marriage and Family, Vol. 63, No. 4, 2001, pp. 1122-1133.

43. Zhi Huayong et al., "Impact of the Global Financial Crisis in Rural China...," art. cit.

44. ACWF-2010, op. cit.

45. Lin Tan, "Quel statut pour la femme chinoise?" (What status for the Chinese woman?), op. cit., pp. 329-348; Zhi Huayong et al., "Impact of the Global Financial Crisis in Rural China...," art. cit.

46. ACWF-2010. op. cit. 
Table 3 - Distribution of men and women by type of activity in 2005 and percentages of women in various sectors, 1990 and 2005.

\begin{tabular}{|c|c|c|c|c|}
\hline & \multirow[b]{2}{*}{ Women } & \multirow[b]{2}{*}{ Men } & \multicolumn{2}{|c|}{$\%$ of women } \\
\hline & & & 1990 & 2005 \\
\hline Government, Party and NGO leaders & 0.7 & 2.2 & 11.2 & 21.6 \\
\hline Technical Staff & 8.2 & 7.0 & 45.1 & 49.4 \\
\hline Offices & 2.6 & 4.6 & 26.0 & 31.8 \\
\hline Trade, services & 13.0 & 11.3 & 46.8 & 48.9 \\
\hline Agriculture, forestry, stock-rearing and fish farming & 62.6 & 52.6 & 47.9 & 49.7 \\
\hline Manufacturing, transports & 12.7 & 22.0 & 35.8 & 32.5 \\
\hline Other & 0.2 & 0.3 & 41.7 & 34.9 \\
\hline TOTAL & 100.00 & 100.0 & 45.0 & 45.4 \\
\hline
\end{tabular}

Source: Population Census Office and National Bureau of Statistics of China, Zhongguo 1990 nian renkou pucha ziliao (Tabulation on the 1990 Population Census of the People's Republic of China), Beijing, Zhongguo renkou chubanshe, 1993; National Statistics Office, 2005 nian quanguo 1\% renkou chouyang diaocha zhuyao shuju (Data of the 2005 1\% Sample Survey), Beijing, Zhongguo tongji chubanshe, 2007, 851 p.

control of their fertility, and participation in taking important decisions within the household, their overall situation has unquestionably improved. The place of women in the family, firstly as girls and then as wives, remains nonetheless subject to various influences that are ultimately not always favourable to them.

On the whole, Chinese women express a high level of satisfaction with their status in the household (in 2010, 85.2 percent of them declared themselves satisfied or very satisfied on this aspect) and with the different roles falling to men and women. However, some of these women (and in total, a quarter of those questioned in the same survey: 24.7 percent) declared they had been the victim of domestic violence, that is to say verbal and/or physical violence, as well as of restriction of personal liberty, economic control, and/or forced sexual relations. ${ }^{(47)}$ Other indicators made available by the ACWF surveys also show that the roles of spouses remain deeply gendered and that women clearly remain under the control of their husbands in many respects. In particular, their participation in domestic decisions, although certainly greater in recent years, is not always automatic. In 2010, three married women out of four participated in decisions that were important to the household, relating to bank loans or financial investments (74.7 percent compared to 50.5 percent in 1990), and an equivalent percentage had a say in the decision to buy or build a family home (74.4 percent compared to 65.6 percent in 1990). Nevertheless, only one women out of seven (13.2 percent in 2010) was a home-owner in her own right (four times fewer than men: 51.7 percent), and one out of four (28.0 percent) was in co-ownership with her husband (compared to 25.6 percent of men). There is similar inequality between single people of both sexes on this aspect, with one bachelor out of five (21.8 percent) owning his own home, compared to one unmarried woman out of 15 (6.9 percent).

This state of affairs is related on the one hand to the aforementioned unequal salaries earned by men and women, which clearly gives them unequal access to financial resources and property, together with the social pressure exercised on people to buy a home, which is less for women than for men. ${ }^{(48)}$ On the other hand, however, it shows the influence, ever strong, of patriarchal traditions that invariably favouring the masculine line and continue to influence family habits, particularly as regards legacies. For example, although enshrined in Chinese law, the right of women to inherit in the same way as men is still far from widespread ${ }^{(49)}$ and is not even universally accepted. The ACWF-2000 survey indicates that only one person out of around four (23.6 percent of women and 28.1 percent of men, compared to 16.2 percent and 21.5 percent respectively ten years earlier) believes that married brothers and sisters have an equal right to inherit. Moreover, an equally small proportion favours a child taking its mother's surname: 34.2 percent of women in 2000 (twice the 1990 figure of 17.1 percent all the same) and 21.2 percent of men (an increase of 7.0 points).

These different results confirm the deep-seated internalisation of gendered roles in Chinese households and their tacit acceptance by the majority of women and men. For example, the division of domestic work remains very unequal, even in households where both husband and wife work. In 2010, the average time a working woman devoted to domestic tasks each day was 2.5 to 3 times longer than the time spent by men (Table 5). However, the majority of married men and women hardly challenged this division of tasks. ${ }^{(50)}$ Overall, the role of the husband as the economic support of the family, and that of the wife as centred on the home and domestic tasks, remain firmly anchored not only in marital practices but also in the expectations that spouses have of each other. ${ }^{(51)}$ These differentiated expectations may therefore explain the unequal access of men and women to educational, financial, and inherited resources, thus perpetuating gender differences. They could also help us understand why, in a labour market that has become highly competitive, the work of Chinese women serves, as elsewhere, ${ }^{(52)}$ as an adjustment variable. When jobs are scarce, family arbitration usually favours the man's job and sacrifices that of the woman, whose contribution to the family income is generally secondary. ${ }^{(53)}$ Women therefore find themselves in competition with men for jobs twice over, once on the labour market and again within the home.

47. ACWF-2010. op. cit.

48. John L. Osburg, Engendering Wealth: China's New Rich and the Rise of an Elite Masculinity, Chicago, The University of Chicago, 2008; Isabelle Attané, Au pays des enfants rares. La Chine vers une catastrophe démographique (In the country where children are rare. China heads for a demographic catastrophe), Paris, Fayard, 2011.

49. Laurel Bossen, "Missing Girls, Land and Population Controls in Rural China," op. cit.

50. Zuo Jiping, Bian Yanjie, "Gendered resources, division of housework, and perceived fairness - Case in urban China," op. cit.

51. Harriet Evans, The Subject of Gender: Daughters and Mothers in Urban China, op. cit.

52. Françoise Battagliola, Histoire du travail des femmes (History of women's work), Paris, La Découverte, 2004.

53. Zhi Huayong et al., "Impact of the Global Financial Crisis in Rural China...," art. cit. 


\section{Box 1 - Progress in reproductive health}

Access to health care and its impact on the well-being and survival of individuals are markers of a society's level of development. Maternal mortality ${ }^{(54)}$ in particular shows the extent to which women receive health care and therefore the place accorded to them in public health policies. The execution of the Millennium Development Goals (see above) led to various national initiatives that have significantly reduced maternal mortality in recent years. In 2008, China recorded 38 maternal deaths per 100,000 births, a very privileged position compared to that of its main neighbours. In the same year, India, for example, recorded a rate of 230 per 100,000, Indonesia 240, and Bangladesh 340. However, China remains well below the level of its more developed neighbours such as South Korea (14) and Japan (6). (55)

The significant drop in maternal mortality, the rate of which has fallen by more than 5 percent per year on average since the early 1990s (Table 4), is mainly the result of the almost universal adoption of hospital births, which have risen from a little over 40 percent in the mid-1980s to more than 90 percent today. ${ }^{(56)}$ It is also the result of better ante-natal care, including in rural areas where in 2010, almost nine pregnancies out of ten (89.4 percent) benefited from medical attention. However, although maternity represents an increasingly lower risk for the survival of Chinese women, these overall performances have not been repeated all over the country. In rural areas, maternal mortality fell by more than a third between 1991 and 2004 but the rate remains more than double that of urban areas (Table 4). In 2006, the rate had fallen to below 10 in Shanghai, Beijing, and Tianjin, that is to say, to a level close to that of Asia's most developed countries, but remained eight times more frequent in the rural areas of Gansu (76), Guizhou (83), Qinghai (99), and Xinjiang (107), with a considerably higher rate in Tibet (246). These disparities are partly due to the fact that hospital births are still uncommon in certain rural areas. In 2006, a third of all births took place at home for women in rural Gansu (33 percent), one out of two in rural Guizhou (49 percent), and two out of three in rural Tibet (64 percent). (57) Moreover, data from ACWF2010 indicates that in China's western and central regions, almost half of all rural women (43.4 percent) had not had a gynaecological examination in the three years preceding the survey (compared to 17.8 percent in the rural zones of Beijing, Tianjin, and Shanghai, and 39.1 percent in the rest of the eastern region).

The anchoring of gendered roles in Chinese households is also due to the persistently high value placed on maternity, despite the dramatic drop in fertility over the last few decades. (58) Yet low fertility is supposedly favourable to the emancipation of women, ${ }^{(59)}$ for two main reasons. Firstly because it mechanically reduces the risks linked to pregnancy and therefore improves their health and reduces their maternal mortality, and secondly, because it is recognised as facilitating the exercise of an activity outside the domestic sphere. Free from the constraints of looking after a large family, women are theoretically more available to carry out a professional activity, which in turn allows them access to greater economic and domestic autonomy. After four decades of birth control, China has distinguished itself in this respect. Fertility there has now attained a comparable or even lower level than that of the most developed countries
Table 4 - Change in the main indicators of reproductive health by place of residence.

\begin{tabular}{|c|c|c|c|}
\hline & China & Urban Areas & Rural Areas \\
\hline \multicolumn{4}{|c|}{ Maternal mortality (deaths of the mother per 100.000 births) } \\
\hline 1991 & 80 & 46.3 & 100.0 \\
\hline 2004 & 48.3 & 26.1 & 63.0 \\
\hline 2010 & 30.0 & n.d. & n.d. \\
\hline \multicolumn{4}{|c|}{ Hospital births (\%) } \\
\hline 1985 & 43.7 & 73.6 & 36.4 \\
\hline 2010 & $94.5^{(\mathrm{A})}$ & $97.2^{(\mathrm{B})}$ & $87.7^{(\mathrm{B})}$ \\
\hline \multicolumn{4}{|c|}{ Births using "new birth delivery methods"(c) $(\%)$} \\
\hline 1991 & 93.7 & 98.1 & 93.2 \\
\hline 2006 & 97.8 & 98.7 & 97.2 \\
\hline
\end{tabular}

1. In 2008 , for all women.

2. In 2010. for women under 35 years old.

3. These methods are based on two main principles: the knowledge of nurses and midwives and the use of sterile instruments in order to reduce the incidence of tetanos and other diseases. Their promotion was followed, from 1978 onwards, by the addition of new requirements to the childbirth protocol (Tan, 2002). These figures apply to all births, whether at home or in hospital.

Sources: Zhongguo jiankang nianjian (China Health Yearbook), Zhonghua renmin gonghe guo weisheng bubian, zhongguo xie he yike daxue chubanshe, 2007, 402 p.;ACWF-2000. op. cit:;ACWF-2010, op. cit.

Graph 2 - Indicators of medical attention to pregnancies for women under 35 at the birth of their last child -2000 and 2010 (as a percentage).

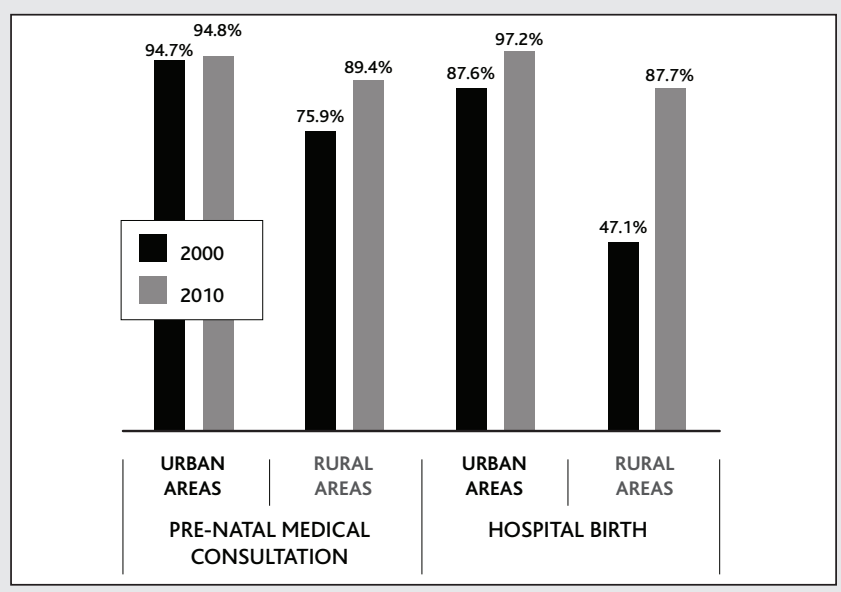

Source: ACWF-2010. op. cit.

54. The maternal mortality rate measures the number of mothers dying during pregnancy and in, or as a result of, childbirth, per 100,000 live births.

55. UNICEF 2008. Information by country and programme, www.unicef.org/infobycountry (consulted on 25 September 2012).

56. Feng X. L., Zhu J., Zhang L., Song L., Hipgrave D., Guo S., Ronsmans C., Guo Y., and Yang Q., "Socioeconomic disparities in maternal mortality in China between 1996 and 2006," BJOG,Vol. 117, No. 12, 2010, pp. 1527-36. Moreover, it must be added that since the mid-2000s, the Chinese Ministry of Health has set up a benefits system for pregnant women in rural areas. The benefit of 500 yuan (around 50 euros) is intended to meet the cost of a hospital birth. It is one of the measures introduced to combat infant and maternal mortality following the MDGs (see above). See An, "China lowers maternal death through subsidizing hospital delivery," 9 September 2011, http://news.xinhuanet.com/english2010/china/2011-09/09/c_131129666.htm (consulted on 25 September 2012).

57. Zhongguo jiankang nianjian (China health yearbook), Zhonghua renmin gonghe guo weisheng bubian, zhongguo xie he yike daxue chubanshe, 2007.

58. Isabelle Attané, Au pays des enfants rares, op. cit.

59. Karen Oppenheim Mason, "Influence du statut familial sur l'autonomie et le pouvoir des femmes mariées dans cinq pays asiatiques" (Influence of family status on the autonomy and power of married women in five Asian countries), in Maria Eugenia Cosio-Zavala, Éric Vilquin (eds.), Statut des femmes et dynamiques familiales (Women's status and family dynamics), Paris, Cicred, 2000, pp. 357-376. 
Table 5 -Time (in hours) devoted each day to domestic tasks by employed persons, by sex.

\begin{tabular}{|l|c|c|c|c|c|c|}
\hline & \multicolumn{3}{|c|}{ Women } & \multicolumn{3}{c|}{$\begin{array}{c}\text { Men of total time devoted to } \\
\text { housework done by women }\end{array}$} \\
\hline & 2000 & 2010 & 2000 & 2010 & 2000 & 2010 \\
\hline Urban areas & 2.9 & 1.7 & 1.2 & 0.7 & 70.2 & 70.3 \\
\hline Rural areas & 4.4 & 2.4 & 1.6 & 0.8 & 73.9 \\
\hline
\end{tabular}

Source : ACWF-2010. op. cit.

(around 1.4-1.5 children on average in China in 2010, ${ }^{(60)}$ compared to 2.3 in 1990 and almost six in 1970). However, reduced fertility has not been accompanied by a growth in the number of women working - quite the contrary. The level of employed women has on the one hand, as a result of its already exceptionally high level in the 1970 s and therefore limited growth potential, prevented the negative correlation effect usually observed between these two phenomena from operating. On the other hand, the effects of the fall in fertility on women's employment have been largely counterbalanced by the liberalisation of the labour market and the disengagement of the state from taking care of children, with the steep rise in the cost of bringing up children, notably in matters of day-care, health, and education, making the reconciliation of family and professional life increasingly difficult and costly. Paradoxically, children, even in the limited numbers now found in most Chinese families, constitute an increasing obstacle to employment for Chinese women. ${ }^{(61)}$ Moreover, the family planning program continues to impose major restrictions on women (notably that of compulsory contraception and the negation of personal fertility desires), thereby limiting their empowerment at the individual and family level.

\section{Gender and number: A complex, little-known relationship}

The highly gendered roles that still exist within the couple are part of a continuum of inequality between the sexes that can be seen throughout the life-span. From this point of view, demographic evolutions, since they are closely dependent on the family and social norms in vigour, shed special light on the situation of Chinese women. It appears that it is in early childhood that the most violent gendered discriminations occur, and threaten in some cases the very survival of girls. Yet the resulting deficit of women could have important consequences for society and its various players, as well as for gender relationships in the not-too-distant future.

\section{Infancy: A crystallisation of gendered discrimination}

Chinese culture has long placed greater value on the male sex, including during childhood. Indeed, every aspect of Chinese patriarchy encourages the preference for boys, who in social representations retain the monopoly of various family responsibilities. A source of pride and social recognition from birth onwards, (62) adult boys guarantee the perpetuation of the family line, the care of their parents in old age, and the transmission of family assets. This is why at various times in Chinese history, when the socio-economic context was such that families could no longer meet the needs of all their children and were forced to limit their number, they chose sons over daughters, creating a deficit of young girls, in particular in the nineteenth century and first half of the twentieth century. ${ }^{(63)}$
Chinese society perpetuates a masculine archetype invested with social roles and skills that, according to a similar feminine archetypal schema, girls cannot match up to, justifying the traditional preference for a son. So whilst births remain strictly limited, girls become undesirable for the simple reason that they deprive their parents of a son, who from both a material and symbolic point of view has no equal. However, over and above the strict limitation of births imposed since the 1970s, behaviours have changed. The desire to have a child is more and more often weighed up against the everincreasing economic burden this places on the family, so today's couples are spontaneously having fewer children. Yet because couples continue to prefer boys, many girls are eliminated even before birth by selective abortion, or die soon after as a result of receiving poorer health care than boys. ${ }^{(64)}$ Over the past 30 years, their share has diminished significantly compared to boys (Graph 3), and the situation continues to get worse. In 2010, 118.0 boys were recorded for every 100 girls in the under- 15 age group (as against 108.5 in 1990 and 113.6 in 2000), that is, a proportion of around 15 percent higher than the norm. ${ }^{(65)}$ Fewer Chinese girls are born, and girls generally do not survive as long as they could on account of the general health and socio-economic context.

Inequalities between the sexes as regards access to health care for very young children are now such that China has become one of the few countries in the world in which the mortality of girls before their first birthday is higher than that of boys. A lower vaccination rate, a longer delay in obtaining medical attention when ill, less recourse to a hospital if needed...in many rural regions, when a son is ill, the parents generally react faster and employ considerable resources to treat him. When a daughter is ill, however, they hesitate to consult a doctor or to take the child to hospital, and on average spend less on health care than for a son. The deterioration of the health system since the economic reforms has in this domain worked against girls, in particular in country areas where access to the health infrastructure remains more difficult than in urban areas. This contribution is ob-

60. Nanfang zhoumou, "Zhongguo xianru chao di shengyulü xianjing" (China falls into the trap of the lowest-low fertility), 24 May 2011, www.infzm.com/content/59364 (consulted on 25 September 2012).

61. Isabelle Attané, Au pays des enfants rares, op. cit.

62. Li Shuzhuo and Zhu Chuzhu, Zhongguo er'tong shengcun xingbie chayi de yanjiu he shixian (Research and community practice on gender difference in child survival in China), Beijing, Zhongguo renkou chubanshe, 2001

63. Chen Wei, "Sex-selective abortions: Evidence from rural east China," Paper given at the 25th UIESP Conference, Tours, France, 2005; Monica Das Gupta and Li Shuzhuo, "Gender bias and marriage squeeze in China, South Korea and India 1920-1990: The effects of war, famine and fertility decline," Development and Change, Vol. 30, No. 3, 1999, pp. 619-652; Lloyd E. Eastman, Family, fields and ancestors, New York, Oxford University Press, 1988.

64. Chen Wei, "Sex-selective abortions: evidence from rural east China"; Li Shuzhuo and Zhu Chuzhu, Zhongguo er'tong..., op. cit.

65. Population Census Office and National Bureau of Statistics of China, Zhongguo 2010 nian renkou pucha ziliao (Tabulation on the 2010 Population Census of the People's Republic of China), Beijing, China Statistics Press, 2012 
Graph 3 - Change in the number of boys for every 100 girls at each age up to 15 years, 1982-2010.

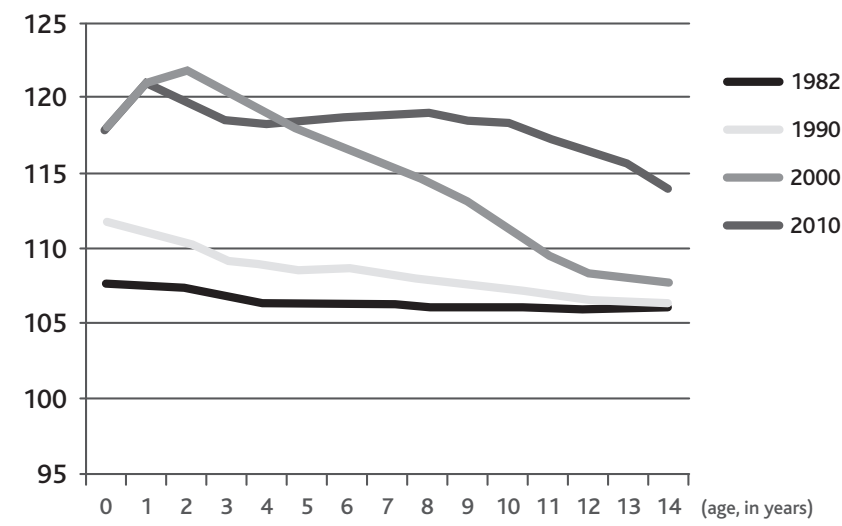

Sources: Population Census Office and National Bureau of Statistics of China, Zhongguo 1982 nian renkou pucha ziliao (Tabulation on the 1982 Population Census of the People's Republic of China) Beijing, Zhongguo renkou chubanshe, 1985, p. 674; Population Census Office and National Bureau of Statistics of China, Zhongguo 1990 nian renkou pucha ziliao (Tabulation on the 1990 Population Census of the People's Republic of China), Beijing, Zhongguo renkou chubanshe, 1993; Population Census Office and National Bureau of Statistics of China, Zhongguo 2000 nian renkou pucha ziliao (Tabulation on the 2000 Population Census of the People's Republic of China), Beijing, China Statistics Press, 2002, p. 1906; Population Census Office and National Bureau of Statistics of China, Zhongguo 2010 nian renkou pucha ziliao (Tabulation on the 2010 Population Census of the People's Republic of China), Beijing, China Statistics Press, 2012.

viously indirect, but there is no doubt that the increase in health costs has forced the poorest households to make a cost/benefit calculation before seeking health care for a child, that its sex is taken into account when the decision is made, and even that certain elementary precautions in terms of both preventive and curative health care are neglected. (66) The slow improvement in the survival of children was therefore accompanied, between the 1970s and 2000s, by ever-increasing differences between the sexes to the detriment of girls. In 2005-2010, according to data from the United Nations, the mortality of children before their first birthday stood at 18.0 per thousand for boys and 26.8 per thousand for girls. ${ }^{(67)}$ However, if parents had given their daughters the same health care as their sons, this figure could have been halved. Each year of the 1990s, therefore, some 110,000 little girls were victims of a premature death before their first birthday, to which must be added the 500 to 600,000 female foetuses a year, victims of selective abortion over this same period. ${ }^{(68)}$

Although discrimination of this nature is only one aspect of the inequalities that persist between the sexes, it continues, in a certain manner, to be nourished by them. Indeed, because Chinese women do not have the same opportunities for social success as men and remain largely invested in roles that have a lesser social value than masculine roles, in most families, sons remain preferable to daughters. For example, "One of the main challenges to be met [to stop the elimination of girls] consists of modifying the rigid custom of patrilocal and patrilinear marriage, the transmission of land rights limited to the masculine heirs of the patrilinear clan, the traditional weakening a daughter has with her biological family after marriage, the dependence on sons for care in old age, as well as other traditional social practices that mean daughters have less value than sons for their family." (69)

The unequal treatment of boys and girls in early childhood, combined with the long-term effects of the comparatively high female mortality that has characterised the greater part of the twentieth century, ${ }^{(70)}$ has made China one of the rare countries in the world with more men than women. After
India (106.4 men for 100 women in 2011) it has the highest sex ratio in the world: 104.9 in 2010, ${ }^{(71)}$ whilst the world average (China and India excluded) stood at 98.5 in 2010. ${ }^{(72)}$ This demographic surplus of males is creating a hitherto unparalleled situation in the documented history of human populations, both in its scale and in its lasting impact on population structure and numbers. ${ }^{(73)}$ In particular, the surplus of males recorded today, especially as regards children, will have progressive repercussions on the adult population as they age. For example, the number of men per 100 women amongst 30-39 year olds will exceed 117 in 2050, that is to say 13 points more than in 2010 (Table 6). According to official estimates, the surplus of men amongst young adults of marriageable age is expected to reach 24 to 30 million in 2020. ${ }^{(74)}$ Moreover, it is precisely when they reach adulthood that the surplus of men will have its most obvious consequences both from an individual and a collective point of view.

\section{What number might do to gender}

The most immediate consequence of this male surplus will be a shortage of potential wives on the marriage market, since there will be significantly more men of marriageable age than women in the same situation. ${ }^{(75)}$ Logically, the difference will be accompanied by an increase in non-elective bachelorhood (76) and an increase in age-gaps between spouses, with non-married men turning

66. Li Shuzhuo and Zhu Chuzhu, Zhongguo er'tong..., op. cit.

67. UN-WPP 2010, United Nations, World population prospects, The 2010 Revision, http://esa.un.org/wpp/unpp/panel_population.htm (consulted on 25 September 2012).

68. Isabelle Attané, Hoping for a Son... The Demographic Masculinisation in China, Berlin, Springer, 2013 [forthcoming].

69. Judith Banister, "Shortage of girls in China today," Journal of Population Research, Vol. 21, No. 1, 2004, pp. 19-45.

70. Stephan Klasen and Claudia Wink, "A turning point in gender bias in mortality? An update on the number of missing women," Population and Development Review, Vol. 28, No. 2, 2002, pp. 285312.

71. Population Census Office and National Bureau of Statistics of China, Zhongguo 2010 nian renkou pucha ziliao (Tabulation on the 2010 Population Census of the People's Republic of China), Beijing, China Statistics Press, 2012

72. UN-WPP 2010, op. cit.

73. Several societies have, at a given moment, recorded an imbalance between the sexes on the marriage market (see Kyle D. Crowder and Stewart E. Tolnay, "A New Marriage Squeeze for Black Women: The Role of Racial Intermarriage by Black Men," Journal of Marriage and Family, Vol. 62, No. 3, 2000, pp. 792-807; V. Hudson and A. M. den Boer, Bare Branches: Security Implications of Asia's Surplus Male Population, London, MIT Press, 2004; Serguei Scherbov and Harrie van Vianen, "Marriage in Russia:A reconstruction," Demographic Research, Vol. 10, 2004). But this imbalance, since it was temporary and only concerned a fraction of the population or was compensated for by behavioural adjustments (see Zeba A. Sathar and M. Framurz Kiani, "Some Consequences of Rising Age at Marriage in Pakistan," The Pakistan Development Review, Vol. 37, No. 4, 1998, pp. 541-556), did not affect them significantly. In China, on the other hand, this imbalance will have repercussions on the size and structure of the population until at least 2050 (Li Shuzhuo, jiang Quanbao, Isabelle Attané, and M.W. Feldman, "Zhongguo de nanhai bianhao he hunyin jiya" [The preference for sons and female deficit on the marriage market in China], Renkou yu jingji, No. 4, 2006, pp. 1-8).

74. Interviews by Yuan Xin, manager of the project "Care for girls," Commission nationale de planification familiale (National Commission on Family Planning), http://book.q9.com/a/20110818/ 000009_2.htm (consulted on 25 September 2012); and Zhai Zhenwu, in Huaxi dushi bao, $17 \mathrm{Au-}$ gust 2011.

75. The shortage of women on the marriage market will also be exacerbated by the numerical gap between the successive cohorts, for when the number of births drops dramatically over the years as it has done in China since the 1970s, the number of boys is greater than the number of girls whom they are eventually supposed to marry, in view of the age gap between spouses. For example, the number of men arriving on the marriage market will be far greater than the number of women several years their junior (see Giovanna M. Merli, Sara Hertog, "Masculine sex ratios, population age structure and the potential spread of HIV in China," Demographic Research, Vol. 22, No. 3, 2010, pp. 63-94)

76. Li Shuzhuo et al., "Zhongguo de nanhai bianhao...," art. cit:; Guo Zhigang and Deng Guosheng, "Nianling jiegou bodong dui hunyin shichang de yingxiang" (The impact of change in population structure on China's marriage market), Zhongguo renkou kexue, No. 2, 1998, pp. 1-8. 
Table 6 - Number of men per 100 women in different age groups -2010 and 2050.

\begin{tabular}{|r|cc|}
\hline & 2010 & 2050 \\
\hline Children (under 15 years) & 120.6 & 111.4 \\
\hline Adultes (15-59 years), of which : & 107.2 & 116.3 \\
\hline$-20-29$ years & 108.1 & 115.0 \\
\hline- 30-39 years & 104.5 & 117.3 \\
\hline$-40-49$ years & 105.3 & 120.3 \\
\hline Elderly people (60 years and over) & 94.2 & 89.5 \\
\hline
\end{tabular}

Source: Calculations made on the basis of United Nations estimates (UN-WPP 2010) United Nations, World Population Prospects, The 2010 Revision, United Nations, available at http://esa un.org/wpp/unpp/panel_population.htm (consulted on 25 September 2012).

towards increasingly younger potential wives or having to wait longer before they marry. ${ }^{(77)}$ By creating greater demand on the part of men for wives, it could also affect conjugal mobility and lead to an increase in divorce. Lastly, the deficit of women could also be accompanied by the development of marriage migration both within China and from neighbouring countries, in particular, Vietnam. ${ }^{(78)}$ In the longer term, if fertility remains stable, the deficit of women and therefore of mothers will lead to a reduction in the birth rate and consequently to a slowingdown of population growth. ${ }^{(79)}$ To these identified and well-documented demographic changes will be added a number of effects on society and individuals that remain unexplored. In particular, the nature of the social transformations brought about by a lasting shortage of women, the strategies and individual issues underlying these transformations, and their consequences for gender relationships and the sexuality of men and women raise many questions: processes of adaptation to this new social and demographic situation will have to be found.

In a situation where there will be fewer adult women than adult men for the foreseeable future, various questions arise. Although the demographic surplus of men is the direct consequence of the low status of women in Chinese society, one such question concerns the way in which this might evolve. Might a relative reduction in the number of women increase their decision-making and negotiation power within the couple and the family? Could this help them escape the domestic sphere? Is it likely to attenuate gendered roles within the family and society or, on the contrary, reinforce them? Lastly, could it contribute to raising their status or, on the contrary, lead to its deterioration? According to certain authors, when there are significantly fewer women than men, their value, and therefore their power, increases and as a result can foster their emancipation, ${ }^{(80)}$ mainly through the practice of hypergamy. ${ }^{(81)}$ For others however, when women become scarcer, men can exercise tighter control over them ${ }^{(82)}$ - control that may, moreover, be exacerbated by an increase in the age-gap between husband and wife, which is commonly declared to be an element in the women's status, an indicator of inequalities within the couple but also of the role and position of women in society. ${ }^{(83)}$ In this case, their economic independence would be limited and their traditional roles of housewife and mother reinforced. Moreover, nothing yet exists to confirm that hypergamy, if it develops, will allow women to achieve greater autonomy from men. In a situation where there is a relative shortage of potential wives, marriage might admittedly become a factor for upward social mobility, since women seeking to marry would be presented with a wider choice of husbands and therefore tend to favour those from a higher socio-economic category who are likely to give them better living conditions. Yet this practice might not be entirely to their advantage. Indeed, whilst women practice hypergamy in the expectation of achieving upward social mobility, ${ }^{\left({ }^{84}\right)}$ men in return look for a physically attractive wife, whose value as a sexual object therefore increases. ${ }^{(85)}$ In the long run, when men have also been affected by the shortage of females and especially by the difficulty of finding a partner and founding a family, will they change their perception of the discrimination against girls that is at the origin of this deficit and therefore, in the long-run, of the image of women and the power relationships between the sexes?

Another uncertainty concerns the effects of the shortage of women on the men themselves. In particular, the increase in bachelorhood, if it is not desired, might not be insignificant for the men concerned. Indeed, in China, a high value is placed on marriage, and the majority of young people continue to think that when people reach adulthood, they should marry, ${ }^{(86)}$ to the extent that for Ownby, ${ }^{(87)}$ "In the eyes of the majority of Chinese, an unmarried man is neither truly adult, nor truly a man." Social norms therefore still heavily influence behaviour. In 2010, at the age of 30, eight men (81.9 percent) and nine women (91.2 percent) out of ten were married. (88) Society remains permeated by Confucian traditions, which place special value on the continuation of the family line and filial piety. ${ }^{\left({ }^{(89)}\right)}$ Yet the latter can only exist through marriage and the production of descendants, generally seen as essential stages in the life of both women and men. Moreover, marriage enables the perpetuation of patrilinear traditions ${ }^{(90)}$ as well as the establishment of new family links that are useful in the development of so-

77. Máire Ní Bhrolcháin, "La flexibilité du marché matrimonial" (The flexibility of the marriage market), Population, Vol. 55, No. 6, 2000, pp. 899-940.

78. Caroline Grillot, Volées, envolées, convolées... Vendues, en fuite, ou resocialisées : les "fiancées" vietnamiennes en Chine (Stolen, disappeared, married... Sold, on the run or resocialised:Vietnamese "fiancées" in China), Paris, Irasec, 2010; Le Bach Duong, Danièle Belanger and Khuat Thu Hong, "Transnational Migration, Marriage and Trafficking at the China-Vietnam border," in Isabelle Attané and C. Z. Guilmoto (eds.), Watering the neighbour's garden: The growing demographic female deficit in Asia, Paris, Cicred, 2007, pp. 393-425.

79. Isabelle Attané, "The Demographic Impact of a Female Deficit in China, 2000-2050," Population and Development Review, Vol. 32, No. 4, 2006, pp. 755-770.

80. Randall Collins, "A Conflict Theory of Sexual Stratification," Social Problems, Vol. 19, No. 1, 1974, pp. 3-21; Marcia Guttentag and Paul L. Secord, Too Many Women? The Sex Ratio Question, Newbury Park (CA), Sage, 1983.

81. Hypergamy is a matrimonial practice that consists of choosing a spouse from a higher socio-economic category.

82. Scott J. South and Katherine Trent, "Sex Ratios and Women's Roles: A Cross National Analysis," American Journal of Sociology, Vol. 93, No. 5, 1988, pp. 1096-1115.

83. Magali Barbieri and Véronique Hertrich, "Écarts d'âge entre conjoints et pratique contraceptive en Afrique sub-saharienne" (Age-gaps between spouses and contraceptive practice in Sub-Saharian Africa), Population, Vol. 60, No. 5, 2005, pp. 725-764.

84. Osburg indicates moreover that the development of female hypergamy might lead to a reconfiguration of the traditional rules of filial piety and of the economic logic used up until now to justify the preference for sons, with parents counting more and more on their daughters to care for them in their old age. Indeed, since sons have to devote a large part of their income to building up capital with which to establish their own home (purchase of an apartment, car, etc.) as a result of this same female hypergamy, they consequently have much less income available to keep their elderly parents. See John L. Osburg, Engendering Wealth..., op. cit.

85. David M. Buss and Michael Barnes, "Preferences in Human Mate Selection," Journal of Personality and Social Psychology, Vol. 50, No. 3, 1986, pp. 559-570

86. Harriet Evans, Women and sexuality in China, New York, Continuum, 1997

87. David Ownby, "Approximations of Chinese Bandits: Perverse Rebels or Frustrated Bachelors?," in S. Brownell and J. Wasserstrom (eds.), Chinese femininities, Chinese masculinities, Berkeley, University of California Press, 2002, pp. 226-250.

88. Population Census Office and National Bureau of Statistics of China, Zhongguo 2010 nian renkou pucha ziliao (Tabulation on the 2010 Population Census of the People's Republic of China), Beijing, China Statistics Press, 2012

89. Yuen Sun-Pong, Law Pui-Lam, and Ho Yuying, Marriage, Gender, and Sex in a Contemporary Village, New York, M. E. Sharpe, 2004, p. 295.

90. Liu Dalin, Yunyu yinyang - Zhongguo xingwenhua xiangzheng (Cultural symbol of China's sex), Chengdu, Sichuan renmin chubanshe, 2005. 
cial and economic networks. ${ }^{(91)}$ Chinese society offers scarcely any alternatives to marriage. Unmarried cohabitation, still very rare, is generally just a preliminary to a formal union, and very little value is placed on celibacy. ${ }^{(92)}$ Moreover, although marriage remains a necessary stage in forming a family, it generally remains, despite a relaxation of the norms in the city, ${ }^{(93)}$ the legitimate framework for sexuality. ${ }^{(94)}$ Heterosexual and monogamous marriage continues therefore to condition access to various family and social prerogatives, marking a dichotomy between married and unmarried adults. ${ }^{(95)}$ Access to sexuality in particular is therefore strongly dependent on marital status, especially amongst men from the lower social categories. ${ }^{(96)}$ In the long term, the shortage of potential female partners may therefore increase inequalities between male social groups, since access to women can be transformed into an indicator of a man's economic status.

The numerical imbalance between the sexes might therefore affect the status of women and gender relationships in more ways than one. It remains to be seen how, in this context, men and women will manage on the one hand to retain the progress made to date in terms of equality between the sexes and on the other, to bring about changes in social norms, especially those governing sexual behaviours and gendered roles within the couple, together with the power relationships and values they underlie, to make them more compatible with the new demographic constraints.

\section{Conclusion}

Although Chinese women have clearly gained in autonomy since the 1950s, notably thanks to developments in education and successive laws protecting their rights and interests, their equality with men is still far from secure, and their situation has been evolving in an ambivalent manner for the last three decades. In tandem with undeniable advances in their access to education, they suffer from growing insecurity in the field of employment, as a result of both the reduction in the jobs available to them and the growing inequalities between men and women's salaries. Within the couple, although relationships between husband and wife remain centred on marriage and reproduction, women often remain dependent on men, both at economic level and as regards decision-making. Lastly, from a strictly demographic point of view, the situation of girls is, in comparison to that of boys, one of the worst that exists. These ambivalent developments constitute a major paradox in Chinese society on its journey to modernisation. Although we are unquestionably seeing the emergence of the individual to the detriment of the group, social modernisation and the overall rise in living standards that have accompanied the economic reforms have not resulted in all individuals being perceived as equally valuable. On the whole, the status of Chinese women often remains inferior to that of men, particularly in public life, and roles within the family and society remain firmly gendered.

Discrimination against women, in particular in childhood, which is the result of their less valued status, poses an important challenge for the Chinese authorities from an individual point of view, with regard to the respect of their rights and accession to greater equality between the sexes. From the point of view of society as a whole, the repercussions of demographic gender-based discrimination will also be considerable, since they will affect current balances not only on the marriage and sexuality market as mentioned, but also on the labour market. The latter is set to become increasingly male, ${ }^{(97)}$ on the one hand requiring a restructuring of men's employment to meet the needs of the workforce in certain sectors of the economy in which women are currently over-represented, and on the other hand leading to a growing marginalisation of women's work in society, with all the limits this is likely to place on the economic empowerment of women. Demographic gender-based discrimination is an acute symptom of the adaptation of individuals and families to new constraints imposed by demographic, economic, and social transitions that are as rapid as they are sudden. It is creating a shortage of women that in turn may well fuel discrimination against a group that is now a permanent minority within Chinese society: women.

\section{Translated by Elizabeth Guill.}

I Isabelle Attané is a demographer and sinologist at the Institut national d'études démographiques (National Institute of Demographic Studies) and habilitated to supervise graduate research (HDR). INED, 133, boulevard Davout, 75980 Paris Cedex 20, France (attane@ined.fr).
91. Graham E. Johnson, "Family strategies and economic transformation in rural China: Some evidence from the Pearl River Delta," in Deborah Davis and Stevan Harrel, Chinese families in the post-Mao era, Berkeley, University of California Press, 1992, pp. 103-136.

92. Li Shuzhuo and Jin Xiaoyi, Dangdai Zhongguo nongcun de zhaozhui hunyin (Uxorilocal marriage in rural China today), Beijing, Shehui kexue wenxian chubanshe, 2006

93. William Parish, Edward O. Laumann, and Sanyu A. Mojola, "Sexual behaviours in China: Trends and Comparisons," Population and Development Review, Vol. 33, No. 4, 2007, pp. 729-756.

94. Joanna McMillan, Sex, science and morality in China, London/New York, Routledge, 2006.

95. Zhang Chunhan and Zhong Zhangbao, "Nongcun daling weihun qingnian chengyin fenxi" (Analysis of the causes of a prolonged bachelorhood in rural China), Qingnian tansuo, No. 1, 2005, pp. 1719.

96. Li Shuzhuo, Zhang Qunlin, Yang Xueyan, and Isabelle Attané, "Male Singlehood, Poverty and Sexuality in Rural China: An Exploratory Survey," Population-E, Vol. 65, No. 4, 2010, pp. 679-694; Isabelle Attané, Zhang Qunlin, Li Shuzhuo, Yang Xueyan, and Christophe Guilmoto, "How bachelorhood affects men's sexuality in a context of female shortage: Some evidence from an exploratory survey in rural Anhui, China," The China Quarterly, September 2013 (in press).

97. In fact, the reduction of the working population by more than 220 million by 2050 (UN-WPP 2010, op. cit.) will mainly concern women, whose numbers may be reduced by 126 million (29 percent) compared to a reduction of 99 million for men (-23 percent). In 2050, 54 percent of China's population aged 15 to 49 years will be male, compared to 51 percent in 2010. 